\title{
Assessment of the health status of populations of the ragworm Nereis diversicolor using biomarkers at different levels of biological organisation
}

\author{
J. Kalman ${ }^{1,2, *}$, F. Palais ${ }^{3}$, J. C. Amiard ${ }^{1}$, C. Mouneyrac ${ }^{1,4}$, A. Muntz ${ }^{1,4}$, J. Blasco ${ }^{2}$, \\ I. Riba ${ }^{2}$, C. Amiard-Triquet ${ }^{1}$ \\ ${ }^{1}$ Université de Nantes, MMS, EA2160, Faculté de pharmacie, 1 rue G. Veil, BP 53508, 44035 Nantes Cedex 1, France \\ ${ }^{2}$ Instituto de Ciencias Marinas de Andalucía (CSIC), Av. República Saharaui, 11510 Puerto Real, Cádiz, Spain \\ ${ }^{3}$ Université de Reims, URVVC-SE EA 2069, Laboratoire d'Eco-Toxicologie, UFR Sciences exactes et naturelles, \\ Moulin de la Housse, BP 1039, 51687 Reims Cedex 2, France \\ ${ }^{4}$ Université Catholique de l'Ouest, Institut de Biologie et Ecologie Appliquée, CEREA, 44 rue Rabelais, \\ 49008 Angers Cedex 1, France
}

\begin{abstract}
We compared behavioural (burrowing speed), biochemical (acetylcholinesterase [AChE] inhibition, activities of digestive enzymes) and physiological (feeding and egestion rates, condition) responses in Nereis diversicolor originating from a multipolluted estuary (Loire estuary) and a relatively clean site (Bay of Bourgneuf) on 3 occasions during spring 2008. Significant inhibition of AChE and digestive enzymes (amylase and carboxymethylcellulase) activities were recorded in individuals from the Loire estuary compared to the reference site. At the individual level no significant intersite differences in burrowing speed were observed when ragworms were exposed to their sediment of origin. No link between AChE activity and burrowing behaviour was found in worms from either site. Cross-tests revealed that behavioural disturbances in locomotion were not due to neurological dysfunction but to avoidance of contaminated sediments. Feeding and egestion rates were depressed significantly in worms originating from the Loire estuary compared to the reference site. These behavioural impairments were accompanied by changes in digestive enzyme activities, which can explain the generally poorer condition of ragworms from the Loire estuary. Temporal changes in responses reported in the present study underline the importance of the fluctuation of environmental factors and thus the need for more than one sampling series to assess the health status of a given site. Disturbances at the different levels of biological organisation are likely explained by environmental contamination either chronic in the Loire estuary or the result of a small oil spill.
\end{abstract}

KEY WORDS: Nereis diversicolor · Estuarine sediment $\cdot$ Biomonitoring $\cdot$ Behavioural impairments Biochemical biomarkers

Resale or republication not permitted without written consent of the publisher

\section{INTRODUCTION}

Coastal and estuarine waters receive contaminants from local anthropogenic sources and through riverine inputs (Eggleton \& Thomas 2004). Estuaries are extremely productive and important feeding, migration and rearing zones (Chapman \& Wang 2001). Most species in estuarine environments live near their tolerance limit due to changing natural factors such as salinity, $\mathrm{pH}$, dissolved oxygen, and redox potential. Since the species are already stressed, any additional stress from pollution will have a greater impact on the physiology, biology and behaviour of organisms (Heugens et al. 2002). It is well established that sediments can act as permanent or temporary traps for material entering the aquatic environment; therefore assessments of estuary sediments are very important (De Gregori et al. 1996). Many authors propose the use 
of sediment toxicity tests to examine the impact of pollutants on the aquatic sedimentary environment (DelValls \& Conradi 2000, Chapman et al. 2002). In addition, field studies provide information about the biological effects of pollutants at various levels of biological organisation.

Although biochemical and physiological biomarkers have been used increasingly in environment toxicology, they are not yet able to predict the effects of contaminants at higher levels of biological organisation. The aim of most ecological risk assessments is to protect populations, communities and ecosystems; only rarely is the goal to protect individuals. Therefore it is important to study the link between the responses of biomarkers at the sub-organismal and supraorganismal levels (Forbes et al. 2006). Studies of biomarkers related to energy metabolism, growth or reproduction (De Coen \& Janssen 2003, Durou et al. 2007b, 2008) as well as behavioural disturbances (Dell'Omo 2002, Amiard-Triquet 2009) appear particularly promising. Behavioural biomarkers are sensitive tools that help us to assess the impact of contaminants at concentrations far below lethal levels. Furthermore, they are non-destructive, allowing behavioural analyses to be easily combined with biochemical or physiological analyses in the framework of multimarker approaches as proposed by many authors (AmiardTriquet 2009).

To assess the behavioural impairments caused by pollutants it is necessary to select species that play a key role in the structure and functioning of the ecosystems. Nereis diversicolor is a common ragworm that lives in U- or Y-shaped burrows in brackish environments (Esselink \& Zwarts 1989, Davey \& Watson 1994) and shows high physiological tolerance to extreme variations in environmental factors (Neuhoff 1979). This omnivorous species may utilize different feeding methods depending on season, biomass and local conditions (Riisgård et al. 1996). Ragworms are important prey for several bottom-dwelling fish and wading birds and may therefore contribute to the transport of contaminants to higher levels in the food chain (Ruus et al. 2002). They can significantly affect biogeochemical processes in sediments through bioturbation (Banta et al. 1999).

Burrowing behaviour of polychaetes exposed to contaminated sediments was investigated by several authors, who highlighted the relationship between the aberration in locomotion and the effects of contaminants (Olla et al. 1984, Burlinson \& Lawrence 2007, Bonnard et al. 2009). The ecological significance of reduced burrowing in contaminated sediments is obvious, as it makes the organisms more vulnerable to predator and wave action (Møhlenberg \& Kiørboe 1983). Acetylcholinesterase (AChE) activity is widely used as a biomarker of exposure to organophosphate (OP) and carbamate (C) pesticides (Bocquené et al. 1990). However, recent studies suggest that other contaminants, including metals and algal toxins, can inhibit the activity of this enzyme (Payne et al. 1996, Najimi et al. 1997, Guilhermino et al. 1998, HamzaChaffai et al. 1998, Lehtonen et al. 2003). The enzyme is responsible for the correct transmission of nerve impulses, and therefore its inhibition may be linked with alterations in burrowing behaviour.

Feeding behaviour has been demonstrated to be a useful and informative sub-lethal endpoint in several studies (Blockwell et al. 1998, Moreira et al. 2006). Impairments of feeding rate at the individual level have demonstrated direct effects on population parameters such as growth and reproduction (Maltby et al. 2001). Feeding depression provoked by pollutants may be related either to avoidance behaviours or to alteration of physiological mechanisms, such as the function of digestive enzymes (Wilding \& Maltby 2006). Toxicant-induced inhibition of digestive activity can result in metabolic disruption, in that energy acquired from nutrition is devoted to defence mechanisms (Holloway et al. 1990). Nereis diversicolor, as an opportunistic species, is considered able to fulfill its energy needs using different feeding strategies: carnivorous as well as filter- and deposit-feeding (Meziane \& Retière 2002 and literature cited therein). Its diet may be composed of either phytoplankton, microphytobenthos, and/or detritus of halophytic plants, i.e. food materials especially rich in storage (e.g. starch) and structural (e.g. cellulose) carbohydrates. Thus, to assay the assimilation impairments, digestive amylolytic and cellulolytic activities of amylase and cellulase enzymes are considered promising biomarkers. Egesting rate has also been proposed as an indicator for assessing sediment toxicity and metabolic status of the organisms (Loureiro et al. 2006, Shipp \& Grant 2006).

Environmental monitoring of coastal and estuarine areas is mainly based on the measurement of those chemicals that are perceived to be relatively easy to analyse (heavy metals, DDT and its metabolites, $\gamma$ hexachlorocyclohexane $[\gamma \mathrm{HCH}], \alpha$-hexachlorocyclohexane $[\alpha \mathrm{HCH}]$, some congeners of polychlorinated biphenyls [PCBs], some individual polycyclic aromatic hydrocarbons [PAHs]). In the case of estuaries in which complex mixtures are present, including many classes of compounds (many persistent organic pollutants) that are not yet accessible to analysis or are extremely expensive to analyse, it remains necessary to develop strategies that allow us to assess if a given ecosystem is under stress or not. According to Lam \& Gray (2003), biomarkers are relatively effective in revealing overall toxicities of complex mixtures, particularly those at a high level of biological organization. The present 
study, therefore, uses many biomarkers to limit chemical analysis and determine if a key species in a potentially impacted estuary is under stress or not when compared to its conspecifics from a (globally) cleaner area.

\section{MATERIALS AND METHODS}

Collection. Worms were collected from 2 sites differentially exposed to anthropogenic pressure (precise locations: $47^{\circ} 16^{\prime} 29.66^{\prime \prime} \mathrm{N}, 2^{\circ} 07^{\prime} 59.76^{\prime \prime} \mathrm{W}$ in the Loire estuary; $46^{\circ} 56^{\prime} 23.08^{\prime \prime} \mathrm{N}, 2^{\circ} 04^{\prime} 40.60^{\prime \prime} \mathrm{W}$ in the Bay of Bourgneuf). The Loire estuary is impacted, notably due to the presence of river settlements - Nantes with 580000 inhabitants and Saint Nazaire with 65000 inhabitants - and associated industrial activities. The Loire estuary lies at the discharge point of a watershed area covering $117000 \mathrm{~km}^{2}$ that is home to important economic, agricultural activities. Moreover, on 16 March 2008, a pipe leak caused the spillage of approximately $180 \mathrm{t}$ of bunker fuel at Donges Refinery, Loire-Atlantique, France (www.cedre.fr/en/spill/ donges/donges.php). The Bay of Bourgneuf, surrounded with fresh- and saltwater marshes, with wide livestock farming, is mainly devoted to oyster culture and is a comparatively clean area. Because it is impossible to analyse all the chemicals that may impair biological responses, the choice of these sites took into account the data on contaminants contained within the framework of the Mussel Watch Programme in France (RNO 2006).

Table 1. Temporal fluctuations of ecological parameters. Air temperature is mean (SD) of temperature registered daily during the month before sampling at Saint Nazaire $(3 \mathrm{~km}$ from the sampling site in the Loire estuary; $49 \mathrm{~km}$ from the sampling place in the Bay of Bourgneuf)

\begin{tabular}{|c|c|c|c|c|}
\hline & \multicolumn{2}{|c|}{$\longrightarrow$ Salinity } & \multicolumn{2}{|c|}{$\longrightarrow$ Temp $\left({ }^{\circ} \mathrm{C}\right)-$} \\
\hline & Bay of Bourgneuf & Loire estuary & Min & $\operatorname{Max}$ \\
\hline Apr & 31.0 & 11.0 & $5.4(3.1)$ & $12.0(2.5)$ \\
\hline May & 32.0 & 16.0 & $10.6(2.5)$ & $19.4(4.1)$ \\
\hline Jun & 29.0 & 21.8 & $11.0(2.4)$ & $20.6(2.5)$ \\
\hline
\end{tabular}

Table 2. Mean (SD) concentrations of different size fractions in sediment cores collected over the whole sampling period from the Bay of

Bourgneuf and the Loire estuary. Results expressed in $\mathrm{g} \mathrm{kg}^{-1}$ dry wt

\begin{tabular}{|lllllll|}
\hline & \multicolumn{6}{c|}{ Size fraction $(\mu \mathrm{m})$} \\
\cline { 2 - 6 } & \multicolumn{1}{c}{$<$} & $2-20$ & $20-50$ & $50-200$ & $200-2000$ \\
\hline Bay of Bourgneuf & $237(7)$ & $103(9)$ & $35(4)$ & $496(30)$ & 132 & $(25)$ \\
Loire estuary & $393(106)$ & $256(72)$ & $86(17)$ & $206(117)$ & 64 & $(47)$ \\
\hline
\end{tabular}

On each sampling occasion, salinity was measured in the water remaining at the surface of the mudflat at low tide, whereas mean air temperature was calculated from daily values available at www.meteociel.fr (Table 1). Grain size was determined in sediment cores (about $20 \mathrm{~cm}$ deep, in agreement with the distribution of ragworms) using gravimetric analysis based on the NF X31-107 French standard method developed by the Institut Départemental d'Analyse et de Conseil (IDAC) working under Good Laboratory Practice. Because deep sediment is relatively stable, mean data are shown for the whole sampling period (Table 2).

In each site, individuals of Nereis diversicolor were handpicked gently at low tide from intertidal mudflats monthly during spring 2008 (mid-March to mid-June). On each occasion 50 specimens were collected at random to determine their condition (relationship between size and weight) as recommended by Durou et al. (2008). Worms of similar weight were taken for behavioural, biochemical and physiological tests monthly during the period mid-April to mid-June. After collection individuals were transported to the laboratory with wet algae or sediment from the site of origin, without seawater, in cold containers. Animals were maintained in aerated containers filled with the natural filtered seawater adjusted to the salinity of the site of origin.

Determination of metal concentrations. Worms were placed in filtered, aerated seawater for $24 \mathrm{~h}$ to depurate the digestive tract. This procedure is used to avoid an overestimation the metal concentration accumulated by the organisms (Depledge \& Rainbow 1990). A total of 10 individuals from each site and at each occasion were heated with suprapure concentrated nitric acid (Carlo Erba). After digestion, concentrations of metals in the diluted aliquots were analyzed by furnace atomic absorption spectrophotometry (FAAS; Zn) or electrothermal atomic absorption spectrophotometry (EAAS; Ag, Cd, Cu, Ni and V) with the Zeeman effect using Varian SpectrAA55 and SpectrAA800 spectrophotometers. Standard addition analyses were performed in an isomedium; added concentrations of each element were +6.25, 12.5, $25 \mathrm{ng} \mathrm{Ag} \mathrm{ml}^{-1} ;+0.5,1$, $2 \mathrm{ng} \mathrm{Cd} \mathrm{ml}{ }^{-1} ; 12.5,25,50 \mathrm{ng} \mathrm{Cu} \mathrm{ml}^{-1} ; 12.5,25,50 \mathrm{ng} \mathrm{V}$ $\mathrm{ml}^{-1}$; for EAAS and +250, 500, $1000 \mathrm{ng} \mathrm{Zn}$ $\mathrm{ml}^{-1}$ for FAAS.

All labware was cleaned in a $10 \%$ hydrochloric acid bath for $24 \mathrm{~h}$ and rinsed 3 times with deionised water before being used. The accuracy of the analysis was checked by digesting certified reference material (TORT-2, Lobster Hepatopancreas Marina Reference Material, National Research Council of Canada). 
Determination of condition. The wet wt was determined using a precision balance. Worms were then fixed with $10 \%$ formolized seawater for storing until analysis. The length of the first 3 worm segments (L3; peristomium, prostomium, and first chaetiger) was measured under a binocular magnifying glass (Gillet \& Torresani 2003).

Behavioural tests. All the behavioural tests were set up in a dark, temperature-controlled room $\left(16^{\circ} \mathrm{C}\right)$ and conducted within $1 \mathrm{wk}$ of collection. Burrowing experiments were carried out as described by Bonnard et al. (2009). Briefly, we used plastic $100 \mathrm{ml}$ containers filled with $5 \mathrm{~cm}$ of wet sediment from the site of origin. Worms were placed on the sediment, and their positions were recorded every 2 min during the first $30 \mathrm{~min}$, then every $5 \mathrm{~min}$ for the next $30 \mathrm{~min}$. The time at which every specimen was totally burrowed was considered in the analysis of results. Cross-burrowing tests were performed as described above using sediment from the other site. A total of 20 worms were submitted to each test. Burrowing speed was described by transferring the percentage of unburrowed organisms to natural logarithm. Individuals from the burrowing tests were recovered for AChE activity measurements.

Egestion rate experiments were performed in plastic containers filled with $100 \mathrm{ml}$ of natural filtered seawater adjusted to the salinity of the site of origin. A total of 20 worms from each site were recovered from the sediment and rinsed with seawater several times to remove sediment particles from the surface. They were then placed into the containers and left for $2 \mathrm{~h}$ without disturbing. At the end of the tests individuals were weighed and kept at $-80^{\circ} \mathrm{C}$ until the analysis of digestive enzymes. Faeces were collected by filtering water through preweighed $3 \mu \mathrm{m}$ cellulose nitrate membrane filters (Whatman), and dried for $24 \mathrm{~h}$ at $60^{\circ} \mathrm{C}$. Egestion rate was expressed as $\mathrm{g}$ faeces produced every $2 \mathrm{~h}$.

The feeding rate of Nereis diversicolor was quantified according to the methodology described by Moreira et al. (2006). Larvae of Artemia salina were used as food. A food ration comprised 100 larvae, previously counted into vials and frozen until use. A total of 20 worms from each site were placed into plastic beakers containing about $30 \mathrm{ml}$ seawater adjusted to the salinity of the site of origin and left for $24 \mathrm{~h}$ without disturbing. Water was changed, and animals were allowed to feed for $1 \mathrm{~h}$. At the end of the test, worms were replaced and rinsed to ensure the complete removal of larvae from the surface, and then weighed. The remaining larvae were counted, and results were expressed as the number of larvae fed per hour.

Determination of the AChE activity. To determine AChE activity, organisms were homogenized on ice in 3 volumes of ice-cold Tris buffer (Tris $50 \mathrm{mM}, \mathrm{NaCl}$ 150 mM, pH 7.4, 0.1 mM antiprotease cocktail) using a
Potter-Elvehjem glass homogenizer fitted with a Teflon pestle. The homogenates were centrifuged at $4{ }^{\circ} \mathrm{C}$ for $30 \mathrm{~min}$ at $15000 \times g($ Scaps \& Borot 2000). Determinations of enzyme activity and total protein concentration were performed in supernatant fractions using UV-visible UVIKON xs and ELx800uv spectrophotometers (BioTek Instruments), respectively. AChE/ChE activity was determined using the method of Ellman et al. (1961), adapted to a microplate reader by Galgani \& Bocquené (1991). Total protein concentration was determined by Bio-Rad Protein Assay based on the method of Bradford (1976).

Determination of digestive enzymes. Amylase (EC.3.2.1.1) and carboxymethylcellulase (CMCase3.2.1.4) activities were assayed according to the method developed by Bernfeld (1955). In order to establish the optimal $\mathrm{pH}$ of enzyme activity, a preliminary study was carried out in the $\mathrm{pH}$ range of 6 to 8 , with increments of 0.5 , and the highest activities were found at $\mathrm{pH} 6.5$ for CMCase and $\mathrm{pH} 7$ for amylase. Organisms were homogenized in deionised water on ice at a ratio of $100 \mathrm{mg} \mathrm{ml}^{-1}$ to $50 \mathrm{mg} \mathrm{ml}^{-1}$ (w/v) for CMCase and amylase, respectively, using a PotterElvehjem glass homogenizer fitted with a Teflon pestle. The homogenates were centrifuged at $4{ }^{\circ} \mathrm{C}$ for $30 \mathrm{~min}$ at $15000 \times \mathrm{g}$. The supernatant was divided into 3 portions and used for subsequent enzyme analyses (amylase activity, CMCase activity and protein analyses). The substrate solutions (starch 1\% for amylase; carboxymethylcellulose $1 \%$ for CMCase) were prepared in $20 \mathrm{mM}$ of phosphate buffer (containing $6 \mathrm{mM}$ $\mathrm{NaCl}) \mathrm{pH} 7$ and $\mathrm{pH} 6.5$, respectively. The reaction mixtures, composed of the enzyme extract $(125 \mu \mathrm{l})$, the appropriate substrate $(125 \mu \mathrm{l})$ and a few drops of toluene, were incubated at $35^{\circ} \mathrm{C}$ for $30 \mathrm{~min}$ (amylase) or $2 \mathrm{~h}$ (CMCase). The reaction was stopped by adding $250 \mu \mathrm{l}$ of dinitrosalicylic acid (DNS) and heating the reaction mixtures for $5 \mathrm{~min}$ in a boiling water bath; mixtures were then cooled in cold running water at least for $10 \mathrm{~min}$. Samples were diluted with $2 \mathrm{ml}$ of distilled water before measuring the optical density at $540 \mathrm{~nm}$. The blanks were prepared by adding the enzyme extract after the DNS reagent. Maltose (concentration range of 0 to $3 \mu \mathrm{mol}$ ) was used for calibration curve. Total protein concentration was determined as described above. Specific activity is expressed as mmol maltose mg protein ${ }^{-1} \mathrm{~min}^{-1}$.

Statistical analysis. The burrowing kinetic curves and the curves showing the relationships between L3 length and wet wt were ln-transformed in order to linearize these data, and then they were compared by using analysis of covariance (ANCOVA) between regression coefficients of the least-square best-fit regression lines. Otherwise, results are presented as mean \pm SD. To define significant differences, normally 
distributed data were analyzed by $t$-test (between 2 groups), 1-way ANOVA (multiple comparisons of means) followed by Tukey's HSD post hoc method. In other cases, the nonparametric Kruskal-Wallis and Mann-Whitney comparison tests were used. Level of significance was established at $\mathrm{p}<0.05$. Statistical analyses were performed by using a standard statistical package (STATISTICA, version 6).

Code of experimental ethics and practice. All procedures and experiments performed on animals were in accordance with the current laws of France.

\section{RESULTS}

\section{Metal concentrations}

Total metal concentrations measured in the whole tissues of Nereis diversicolor are presented in Fig. 1. Concentrations of $\mathrm{Ag}(t=3.0973, \mathrm{p}=0.0062 ; t=4.14$, $\mathrm{p}=0.0006 ; t=3.1375, \mathrm{p}=0.0057$ in April, May and June, respectively), $C d(t=3.44, \mathrm{p}=0.0031 ; t=7.19$, $\mathrm{p}<0.0001 ; t=9.6678, \mathrm{p}<0.0001$ in April, May and June, respectively) and $\mathrm{Cu}(t=4.268, \mathrm{p}=0.0005$; $t=$ 3.995, $\mathrm{p}=0.0008$ in April and June, respectively) were significantly higher in worms from the Loire except on one occasion ( $\mathrm{Cu}$ in May). In the case of $\mathrm{V}$, an intersite difference was observed only in April; then the concentrations in the Loire estuary decreased until they reached levels determined in specimens from the reference site. No significant intersite differences were detected for $\mathrm{Ni}$ and $\mathrm{Zn}$, except in May for Zn, with the highest concentration determined in specimens from the Bay of Bourgneuf. Concerning temporal variations, the highest concentrations of $\mathrm{Ag}, \mathrm{Cd}, \mathrm{Cu}$ and $\mathrm{Zn}$ were recorded in April at both sites. Individuals from Loire estuary exhibited significantly higher $\mathrm{V}$ concentrations in April than those measured in the next months.

\section{Condition}

The relationship between size as L3 and wet wt is depicted for each site and each month in Table 3. Except in April, at identical size, the weight of ragworms was higher for specimens originating from the

Fig. 1. Nereis diversicolor. Mean concentrations (+ SD) of metals measured in the whole body of worms originating from the Bay of Bourgneuf (B) and Loire estuary (L). Data are expressed as $\mu \mathrm{g} \mathrm{g}^{-1}$ wet wt. ${ }^{*}$ Significant differences $(\mathrm{p}<0.05)$ between the 2 sampling points in a given month. Significance of seasonal changes at each sampling site is indicated by lower case letters: means with the same letter do not differ significantly
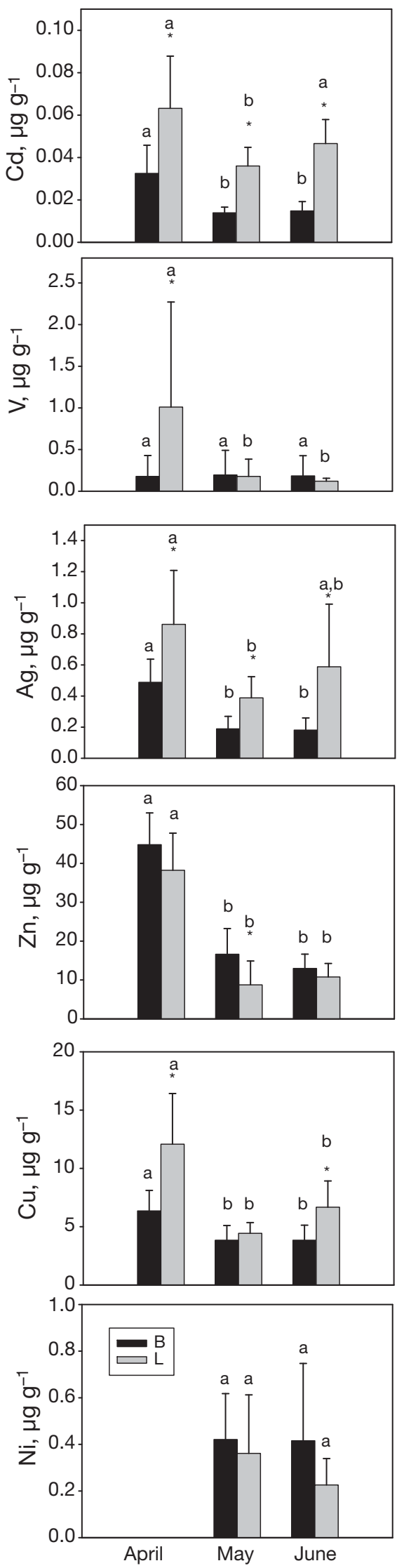
Table 3. Relationship between the length (L3) and wet wt of worms originating from the Bay of Bourgneuf and the Loire estuary. $p=$ probability of intersite differences

\begin{tabular}{|c|c|c|c|c|}
\hline Month & Sampling site & Equation & $\mathrm{R}^{2}$ & $\mathrm{p}$ \\
\hline March & $\begin{array}{l}\text { Bay of Bourgneuf } \\
\text { Loire estuary }\end{array}$ & $\begin{array}{l}y=0.019 \mathrm{e}^{1.181 x} \\
y=0.025 \mathrm{e}^{0.957 x}\end{array}$ & $\left.\begin{array}{l}0.514 \\
0.296\end{array}\right)$ & 0.4 \\
\hline April & $\begin{array}{l}\text { Bay of Bourgneuf } \\
\text { Loire estuary }\end{array}$ & $\begin{array}{l}y=0.005 \mathrm{e}^{1.637 x} \\
y=0.001 \mathrm{e}^{2.215 x}\end{array}$ & $\begin{array}{l}0.750 \\
0.769\end{array}$ & 0.004 \\
\hline May & $\begin{array}{l}\text { Bay of Bourgneuf } \\
\text { Loire estuary }\end{array}$ & $\begin{array}{l}y=0.011 \mathrm{e}^{1.481 x} \\
y=0.013 \mathrm{e}^{1.278 x}\end{array}$ & $\begin{array}{l}0.666 \\
0.625\end{array}$ & 0.006 \\
\hline June & $\begin{array}{l}\text { Bay of Bourgneuf } \\
\text { Loire estuary }\end{array}$ & $\begin{array}{l}y=0.010 \mathrm{e}^{1.593 x} \\
y=0.005 \mathrm{e}^{1.800 x}\end{array}$ & $\begin{array}{l}0.554 \\
0.622\end{array}$ & 0.08 \\
\hline
\end{tabular}

Bay of Bourgneuf, even if this difference was not always significant $(\mathrm{p}=0.4, \mathrm{p}=0.004, \mathrm{p}=0.08$, respectively in March, May and June). Conversely, in April, wet wt at identical size was significantly higher in specimens from the Loire $(p=0.006)$.

\section{Burrowing tests}

When worms were allowed to burrow in their sediment of origin, intersite differences were negligible (Fig. 2). The slopes of the ln-transformed kinetic curves are depicted in Table 4. For specimens from the Loire estuary, the highest slope was seen in April $(-0.238)$, followed by a decrease in May $(-0.185)$, and by June the slope had reached very similar value to that noted in April (-0.220). Specimens from the Bay of Bourgneuf were most active in April (-0.217), while

Table 4. Nereis diversicolor. Slopes and $\mathrm{R}^{2}$ of burrowing kinetic curves obtained from tests using specimens originating from the Bay of Bourgneuf (B) and Loire estuary (L). Individuals were allowed to burrow in the sediment of origin and in the sediment of the other site

\begin{tabular}{|lcccc|}
\hline \multirow{2}{*}{ Month } & Individuals & Sediment & Test slope & $\mathrm{R}^{2}$ \\
\hline April & B & B & -0.217 & 0.94 \\
& L & L & -0.238 & 0.79 \\
& B & L & -0.076 & 0.87 \\
May & L & B & -0.451 & 0.83 \\
& B & B & -0.149 & 0.90 \\
& L & L & -0.185 & 0.84 \\
June & B & L & -0.146 & 0.83 \\
& L & B & -0.244 & 0.83 \\
& B & B & -0.183 & 0.84 \\
& L & L & -0.220 & 0.76 \\
& B & L & -0.160 & 0.91 \\
& L & B & -0.230 & 0.77 \\
\hline \multirow{6}{*}{} & & & & \\
& & & & \\
& & & & \\
& & & &
\end{tabular}

the burrowing speed declined in May (-0.146). Crossburrowing tests were carried out in order to compare the behaviour of Nereis diversicolor. When individuals from the Bay of Bourgneuf were exposed to sediment from the Loire estuary, burrowing speed was lower compared to the sediment of origin in April (0.0756), while for the next months no significant differences were seen (0.1458 and 0.1596 in May and June, respectively). Conversely, ragworms from the Loire estuary showed higher activity in the presence of sediment from the Bay of Bourgneuf than in the presence of their sediment of origin in each month. The difference in the slopes of kinetic curves decreased from April to June.
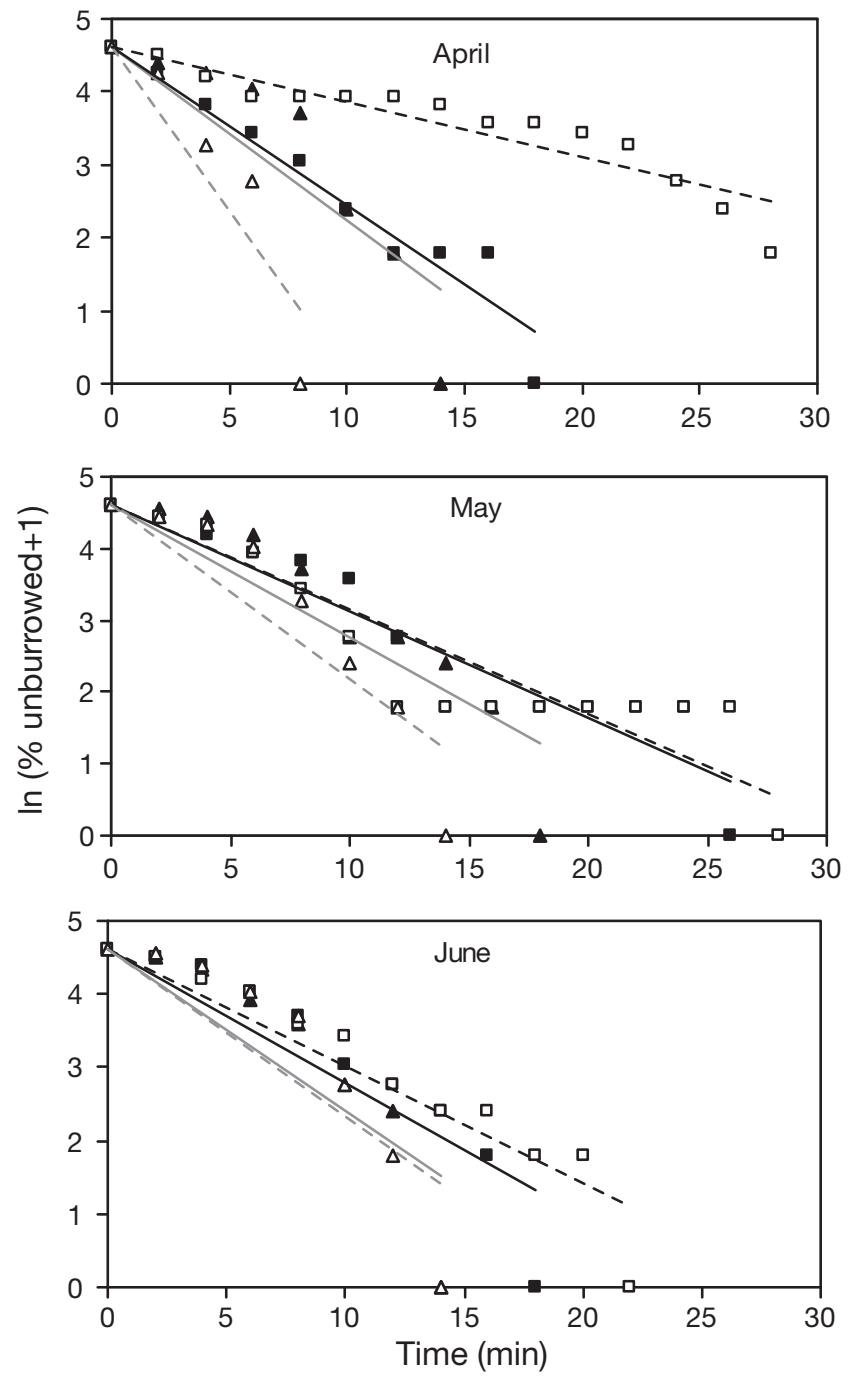

Fig. 2. Nereis diversicolor. Cross-tests carried out on 3 occasions to compare burrowing kinetics of worms originating from the Bay of Bourgneuf $(\boldsymbol{\square}, \square)$ and Loire estuary $(\boldsymbol{\Lambda}, \Delta)$ in their sediment of origin (filled symbols) and in the sediment from the other site (open symbols) 


\section{Egestion and feeding rates}

Significant intersite differences were observed on each occasion, with egestion rates being higher in worms from the Bay of Bourgneuf $(0.009 \pm 0.002$, $0.011 \pm 0.005$ and $0.009 \pm 0.000 \mathrm{~g}$ faeces per $2 \mathrm{~h}$ in April, May and June, respectively) compared to those found in worms from Loire estuary $(0.005 \pm 0.000$, $0.007 \pm 0.002$ and $0.003 \pm 0.000 \mathrm{~g}$ faeces per $2 \mathrm{~h}$ in April, May and June, respectively), as shown in Fig. 3. Significant temporary changes were detected only in worms originating from the Loire estuary, showing the highest value in May (ANOVA, $F=16.32$, p < 0.001).

For the results obtained from the feeding rate experiment, significant intersite differences were recorded in May and June $(t=3.13, \mathrm{p}=0.003 ; t=3.87, \mathrm{p}<0.001$,

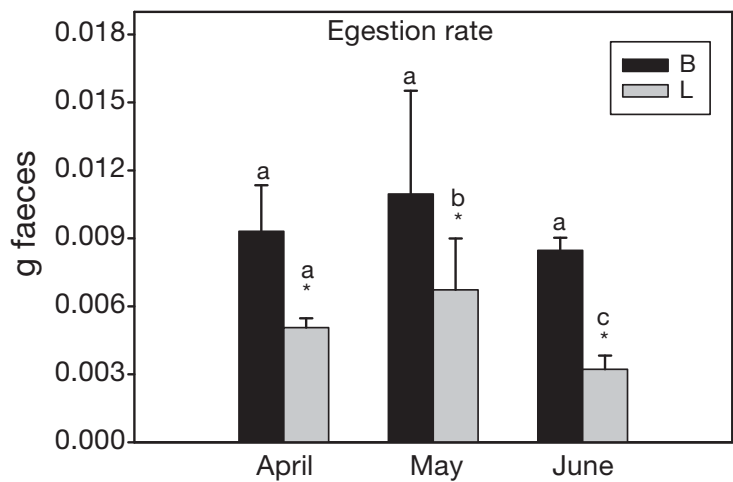

Fig. 3. Nereis diversicolor. Mean egestion rate $(+\mathrm{SD})$ of worms originating from the Bay of Bourgneuf (B) and Loire estuary (L) recorded after $2 \mathrm{~h}$. ${ }^{*}$ Significant differences $(\mathrm{p}<$ 0.05 ) between the 2 sampling points on a given month. Significance of seasonal changes at each sampling site is indicated by lower case letters: means with the same letter do not differ significantly

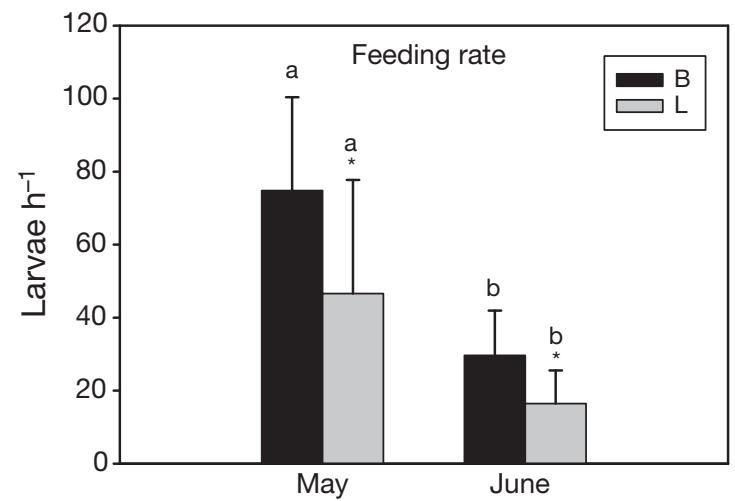

Fig. 4. Nereis diversicolor. Mean feeding rate (+SD) of worms originating from the Bay of Bourgneuf (B) and Loire estuary (L). Data are expressed as number of larvae fed by ragworms after $1 \mathrm{~h} .{ }^{*}$ Significant differences $(\mathrm{p}<0.05)$ between the 2 sampling points on a given month. Significance of seasonal changes at each sampling site is indicated by lower case letters: means with the same letter do not differ significantly respectively), with lower values for the ragworms collected from the Loire estuary (Fig. 4). Significant decreases in feeding rate were observed in each group as well, from May $(74.8 \pm 25.6$ and $46.6 \pm 31.1$ larvae $\left.\mathrm{h}^{-1}\right)$ to June $\left(29.65 \pm 12.26\right.$ and $16.45 \pm 9.06{\text { larvae } \mathrm{h}^{-1}}^{-1}$ for Bay of Bourgneuf and Loire estuary, respectively).

\section{Biochemical markers}

Significant inhibition of AChE activity was observed in worms from the Loire estuary compared to those from the Bay of Bourgneuf for each month $(t=3.28, \mathrm{p}=$ 0.001 in April; $t=22.29$, $\mathrm{p}<0.001$ in May; $t=18.81, \mathrm{p}<$ 0.001 in June) (Fig. 5). Due to the significantly increasing activity in individuals from the Bay of Bourgneuf (from $19.86 \pm 5.03$ to $32.75 \pm 6.47 \mathrm{nmol} \mathrm{min}{ }^{-1} \mathrm{mg}_{\text {prot }}{ }^{-1}$ from May to June, respectively) differences between the 2 sites increased as well. AChE activity in individuals originating from the Loire estuary displayed significant temporal changes (Kruskal-Wallis, $\mathrm{H}=71.25$, $\mathrm{p}<0.001)$, as the highest value was determined in

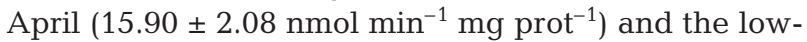
est activity in May $\left(10.38 \pm 2.14 \mathrm{nmol} \mathrm{min}{ }^{-1} \mathrm{mg} \mathrm{prot}^{-1}\right)$.

The specific activity of both digestive enzymes was significantly higher in organisms from the Bay of Bourgneuf, with the difference being more visible in the case of amylase activity, where it reached 2 orders of magnitude (Fig. 6). In individuals from the Loire estuary, no significant temporal changes of the specific activities of CMCase and amylase were observed. In individuals from the Bay of Bourgneuf, the highest values for both CMCase and amylase activities were detected in April $(0.0077 \pm 0.0028$ and $0.1966 \pm 0.0888$ $\mathrm{mM}$ maltose $\mathrm{min}^{-1} \mathrm{mg}$ prot $^{-1}$, respectively), while the

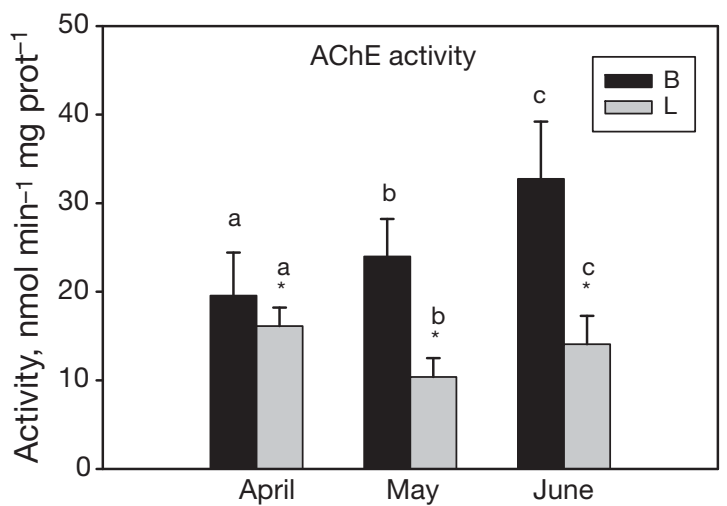

Fig. 5. Nereis diversicolor. Mean activity (+SD) of acetylcholinesterase (AChE) of the whole body of worms originating from the Bay of Bourgneuf (B) and Loire estuary (L). *Significant differences $(\mathrm{p}<0.05)$ between the 2 sampling points on a given month. Significance of seasonal changes at each sampling site is indicated by lower case letters: means with the same letter do not differ significantly 


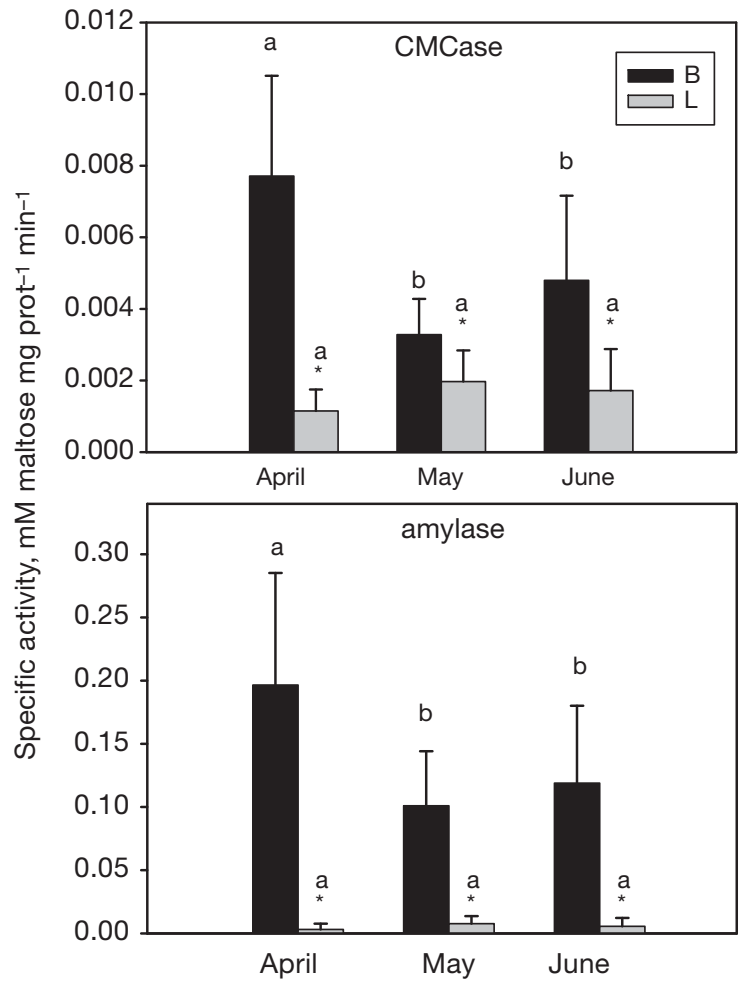

Fig. 6. Nereis diversicolor. Mean digestive enzyme activities (+SD) determined in the whole body of worms originating from the Bay of Bourgneuf (B) and Loire estuary (L). *Significant differences $(p<0.05)$ between the 2 sampling points on a given month. Within each panel, means with the same lower case letter above the bars do not differ significantly

next month they decreased significantly (0.0033 \pm 0.0010 and $0.1010 \pm 0.0432 \mathrm{mM}$ maltose $\mathrm{min}^{-1} \mathrm{mg}$ $\operatorname{prot}^{-1}$, respectively).

\section{DISCUSSION}

In the present study behavioural, biochemical and physiological responses of Nereis diversicolor collected from a multipolluted estuary (Loire estuary) and a comparatively clean site (Bay of Bourgneuf) were investigated on 3 occasions during spring 2008. Both sites, the Bay of Bourgneuf as well as the Loire estuary, are being monitored within the framework of the Mussel Watch Programme in France (RNO 2006). N. diversicolor has been proposed as a good monitor of sediment metal bioavailabilities (Díez et al. 2000, Poirier et al. 2006). Trace metal analyses showing noticeable bioaccumulation in ragworms from the Loire are in agreement with anthropogenic pressure existing in large estuaries. We can conclude that trace metals in general were present at higher levels in organisms in
April. Several factors, both ecological (salinity, temperature) and biological (regulation of bioaccumulated concentrations of essential metals, biological cycle, size), can contribute to temporal variations (Díez et al. 2000, Poirier et al. 2006 and literature quoted therein). In the Loire estuary, the temporal variation of biomass of $N$. diversicolor was surveyed by Gillet \& Torresani (2003). Lowest values were recorded in winter, while during spring/summer an increase in biomass of this ragworm was observed. Changes in biomass may relate to the temporal variation of metal bioaccumulation determined in the present study, as growth represents a factor of biological dilution.

The relatively high concentration of $\mathrm{V}$ measured in worms originating from Loire estuary in April is probably due to a small oil spill that occurred in March (see 'Collection' above). PAHs analyses carried out monthly over the entire sampling period in superficial sediments (showing recent contamination according to Amiard et al. [2009]) by an official laboratory (Institut Départemental d'Analyse et de Conseil, Comité Français d'Accréditation [COFRAC] accreditation) showed lower concentrations in the Bay of Bourgneuf (595 $\pm 242 \mu \mathrm{g} \mathrm{kg}^{-1}$ dry wt on avg.) than in the Loire estuary $\left(1332 \pm 400 \mu \mathrm{g} \mathrm{kg}^{-1}\right.$ dry wt on avg., April sample excluded) with a value of $5934 \mathrm{\mu g} \mathrm{kg}^{-1}$ dry wt 1 mo after the accident of March 2008. V has been suggested as an indicator of pollution by petroleum hydrocarbons by several authors; Amiard et al. (2004) and Chiffoleau et al. (2004) found enhanced V levels in the mollusk Mytilus edulis, periwinkle Littorina littorina, dogwhelk Nucella lapillus and oyster Crassostrea gigas following the 'Erika' oil spill. Beside V, Ni seemed to be a good tracer of petroleum pollution (Amiard et al. 2004) showing a delayed accumulation in 3 benthic invertebrates. In the present study, Ni concentrations in worms were not elevated 3 months after the oil spill.

At identical size, ragworm weight was generally higher for individuals originating from the Bay of Bourgneuf, even if the differences to those from the Loire estuary were moderate. Nereis diversicolor originating from a contaminated site (Seine estuary) showed a depletion of energy reserves compared with individuals originating from a comparatively clean site (Authie estuary), although the former were more able to cope with Zn (Durou et al. 2005). Processes responsible for tolerance may interfere with any allocations of energy for growth and reproduction (Calow 1991). The consequences are manifested in the reduced condition of individuals originating from contaminated sites. Conversely, in April, weight at identical size was higher in ragworms from the Loire estuary. According to Spies et al. (1988), responses of benthic populations to crude oil are similar to those expected from enrich- 
ment by other sources of organic matter. The ragworm as an opportunistic species (Meziane \& Retière 2002) may have taken advantage of this situation. In any case, the intersite differences between ragworms from the Loire estuary and the Bay of Bourgneuf are not as marked as those reported for the same species originating from the Seine and Authie estuaries (Durou et al. 2008). This is not surprising, as the Seine estuary is the most polluted estuary in France, as reported in the Mussel Watch Programme in France (RNO 2006) and a number of other scientific studies (Amiard-Triquet \& Rainbow 2009), whereas the Loire estuary, despite being polluted, does not exhibit such high concentrations of many contaminants (Bragigand et al. 2006, RNO 2006). Metal concentrations (Cd, Ag, Cu and Zn) measured in worms from the Loire estuary compared to those reported by Poirier et al. (2006) from the Seine estuary reaffirm these findings.

It is essential for Nereis diversicolor individuals to be buried in the sediment for several reasons. They may be translocated by currents to unfavourable habitats, or they can become more exposed to predators. Thus, burrowing activity can be considered an ecologically relevant behaviour. Changes in burrowing speed have been proposed as a sensitive endpoint to assess the sublethal effects of contaminants (Byrne \& O'Halloran 2001). Previous studies demonstrated the effects of contaminated sediment on burrowing speed in aquatic organisms. Reduced burrowing activities in contaminated sediments were reported in Nereis (Neanthes) virens by Olla et al. (1984); in Tubifex tubifex by Lagauzère et al. (2009); in Macoma baltica, Cerastoderma edule, Abra alba, N. diversicolor and Scoloplos armiger by Møhlenberg \& Kiørboe (1983); in Corbicula fluminea by Cooper \& Bidwell (2006); and in N. diversicolor and Scrobicularia plana by Bonnard et al. (2009). Cross-tests were carried out in order to examine the causes of the behavioural disturbances. The reduced burrowing activity of worms from the Bay of Bourgneuf exposed to sediment from the Loire estuary, as well as the increased activity of worms from the Loire estuary allowed to burrow in sediment from the other site, suggests avoidance toward sediment from the Loire estuary. This observation is in agreement with previous results obtained with $N$. diversicolor (Mouneyrac et al. in press), showing that independent of any special event, the sediment quality is often lower in the Loire estuary. This cannot be attributed to differences in grain size (higher in the reference site than in the Loire estuary; see Table 2) since Bonnard et al. (2009) have shown that burrowing in relatively coarse sediment required acclimation of the ragworms. Clear behavioural changes were detected in April, while nearly no differences were seen in May and June. Thus disturbances in burrowing behaviour are probably a consequence of oil contamination. When the petroleum contamination was reduced, the behaviour of worms seemed to be restored.

Links between behavioural impairment and neurotoxicity revealed by $\mathrm{AChE}$ inhibition are well documented for aquatic biota (Amiard-Triquet 2009). In contrast, inhibition of AChE activity was not related to burrowing activity in the present study. In spite of the decrease in AChE activity, ragworms from the Loire estuary were not less active burrowing in their sediment of origin. If burrowing activity was disturbed due to avoidance, unsurprisingly there was no consistent relationship between AChE activity and behaviour. Bonnard et al. (2009) investigated the effect of $\mathrm{Cu}$ on the 2 above-mentioned biomarkers using Nereis diversicolor and Scrobicularia plana. In agreement with the results of the present study, no link between burrowing speed and activity of AChE was shown. Scaps \& Borot (2000) pointed out the effects of 2 abiotic factors, important for estuaries, namely temperature (12 or $20^{\circ} \mathrm{C}$ ) and salinity (15 to $30 \%$ o) on the AChE activity in $N$. diversicolor. The effects were short-term stress effects observed under laboratory conditions. When AChE activity was determined in ragworms collected within a small coastal estuary in 2 areas separated by a few $\mathrm{km}$ at salinities of 13 and $30 \%$, no significant differences $\left(13.37 \pm 5.85\right.$ and $15.16 \pm 5.74 \mathrm{nmol} \mathrm{min}^{-1} \mathrm{mg}$ $\operatorname{prot}^{-1}$, respectively) were observed (Kalman et al. unpubl.). Several studies have demonstrated inhibition of AChE activity in organisms from contaminated sites (Pérez et al. 2004, Ait Alla et al. 2006, Durou et al. 2007a, Solé et al. 2009). We presented significant temporal changes for AChE activities in individuals from both sites. Similarly, temporal changes were observed in the Seine estuary (France) during a 3 yr program with quarterly sampling (Durou et al. 2007a). The origin of these changes cannot be easily designated since, as mentioned above, several classes of environmental contaminants - occurring in a multipolluted estuaryhave shown the potential to decrease the enzyme activity.

Concerning the behavioural biomarkers, the present study shows that they followed the same trend, since significant reduction on feeding and egestion rates were observed from May to June in individuals originating from the Loire estuary compared to the reference site. Feeding rate has been increasingly used as a sublethal endpoint to measure toxicological responses (Maltby 1999). Toxicant-induced reduction in feeding rate is likely associated with reduction in the organism's energy assimilation, which can cause impairment in energy allocation to basal metabolisms such as growth, reproduction and survival (Holloway et al. 1990). Another parameter related to feeding rate that can also help in estimating the metabolic status of indi- 
viduals is egestion rate. Alterations of feeding rate were observed by Moreira et al. (2006) in Nereis diversicolor exposed to contaminated sediment, by McLoughlin et al. (2000) in the amphipod Gammarus pulex exposed to toxic chemicals, and by Wilding \& Maltby (2006) in the same species exposed to Zn. No inhibition, but rather an increase in feeding rate in shrimp Litopenaeus vanammei exposed to methyl parathion, was revealed by Comoglio et al. (2005); they suggested that this response might be due to the requirement for higher maintenance costs. Méndez (2006) reported significant decline in egestion rate in the polychaete Capitella sp. I exposed to teflubenzuron. In the marine gastropod Hydrobia ulvae the feeding rate-assessed by measuring the production of faecal pellets-was decreased in metal-rich sediments (Shipp \& Grant 2006). Loureiro et al. (2006) showed depression in feeding rate as well as in egestion rate of the isopod Porcellionides pruinosus fed contaminated food. Conversely, higher assimilation efficiency was observed in the contaminated group. The authors stated that as a consequence of less consumption, food must have stayed longer so that more nutrients could be assimilated. Wilding \& Maltby (2006) assumed that impairments in feeding rate could result either from physiological effects arising through ingestion of contaminated food or from behavioural avoidance.

Determination of digestive enzyme activities has been considered an indicative tool for assessing the physiological status of organism. Inhibitions of amylase and cellulase in Daphnia magna after short-term exposure to $\mathrm{Hg}$ and $\mathrm{Cd}$ were reported by De Coen \& Janssen (1997). In 11 freshwater teleost species exposed to $50 \mathrm{mg} \mathrm{Cd}$ $\mathrm{l}^{-1}$, amylase activity was significantly lowered (Golovanova et al. 1999). In the present study, clear intersite differences pointed out the adverse effect of environmental conditions on the activities of these enzymes. Changes in digestive enzyme activities can occur not only by pollution but also by the interruption of food supply, as reported by Albentosa \& Moyano (2008), who reported inhibition of enzyme activity in the clams Ruditapes decussatus and Venerupis pullastra after starvation. Thus they proposed the activity of digestive enzymes, especially amylase, as a suitable indicator of nutritional status for both species.
The results of the present study demonstrate the usefulness of Nereis diversicolor as a sentinel species for biomonitoring based on many different biomarkers and for revealing intersite differences even in a moderately impacted estuary such as the Loire estuary. At the infraorganism level, biomarkers based on biochemical changes (digestive enzymes and AChE activity) were significantly affected by environmental conditions. At the individual level, feeding rate was depleted - as was egestion rate-in the Loire estuary, an impairment that, in addition to disturbed assimilation (due to decreased digestive enzymes activity), can explain the generally poorer condition of the ragworms from the Loire estuary. At the limit between individual and supraindividual levels of biological organisation, disturbances in locomotion were not linked to physiological impairments such as AChE inhibition, probably due to avoidance toward contaminated sediment. In the present study, environmental contaminationeither chronic in a large estuary versus a comparatively clean site or associated with a small oil spillappeared to be the most likely explanation for the observed disturbances.

Based on our conclusions, we propose a strategy that links chemical stress with a risk of local extinction in estuarine and coastal areas, based on sentinel species

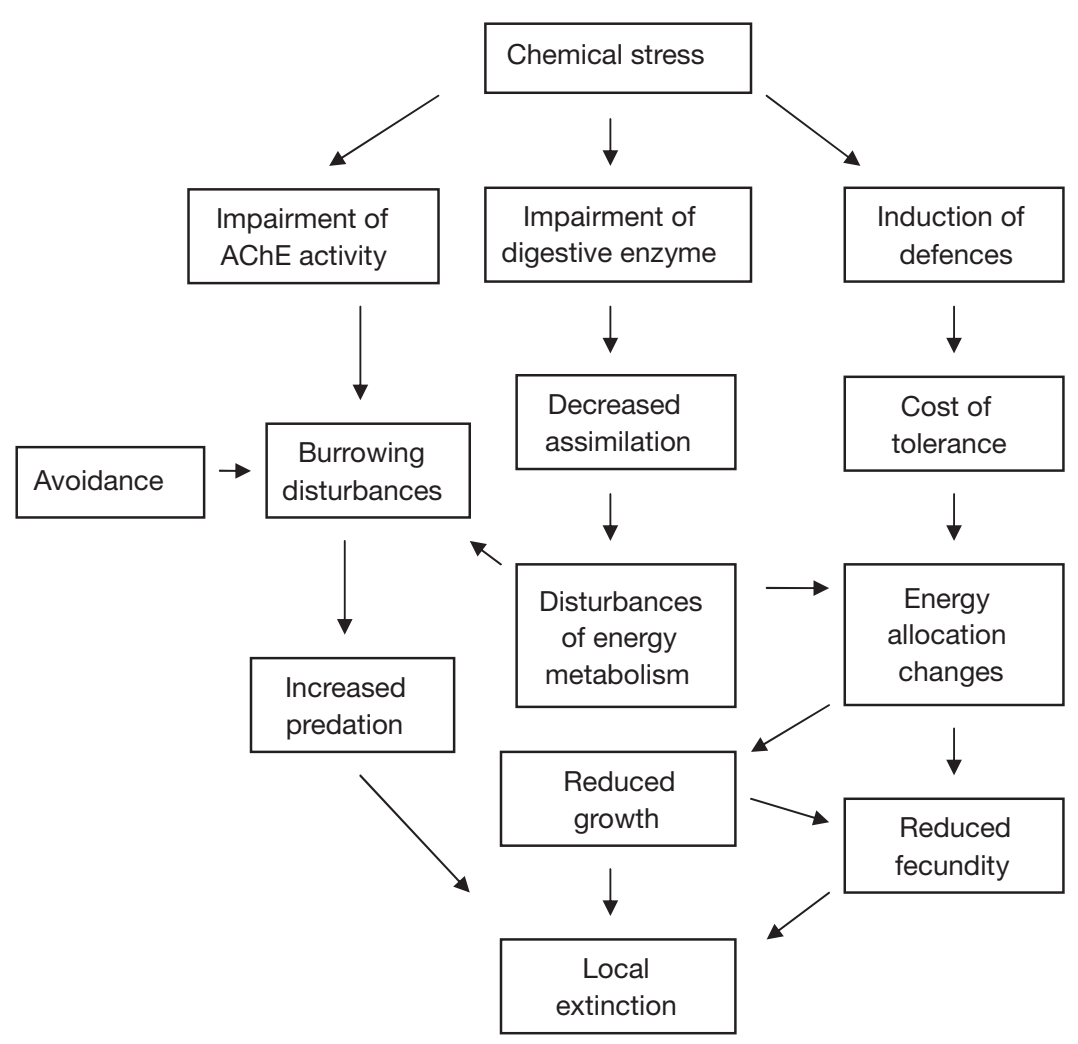

Fig. 7. Linking impairments of invertebrate responses at different levels of biological organisation 
such as Nereis diversicolor but also other sentinels such as those proposed in the ECOMAN project (Galloway et al. 2006). Cascading effects may be assumed from impairments of biological responses in the infraindividual (as early and sensitive indices) through to the individual and supraindividual (for their high ecological relevance) levels (Fig. 7). Reduced feeding and impairment of digestive enzymes can lead to reduced energy intake. In addition to this impairment of energy metabolism, activation of defences (metallothionein induction, increased activity of glutathione-S-transferase, etc.) can result in a cost of tolerance, leading to changes in energy allocation with implications for growth and reproduction and potential effects at the population level. In parallel, neurotoxic effects may be revealed by determining levels of AChE activity, a core biomarker whose relationship with behavioural disturbances is well documented. In addition to feeding, burrowing of endobenthic species is also a behaviour of interest, controlling the relationship between predator and prey. Such a comprehensive approach would allow deciding protective procedures well before the situation has reached a point at which remediation is nearly impossible.

Acknowledgements. J.K. is grateful to the I3P program of Spanish National Research Council for support during her stay at the University of Nantes. Thanks are given to I. Boldina for her help during the improvement of enzymatic methodology. We are grateful to S. Moreira and L. Guilhermino for providing us with the detailed protocol of the postfeeding rate experiment.

\section{LITERATURE CITED}

Ait Alla A, Mouneyrac C, Durou C, Moukrim A, Pellerin J (2006) Tolerance and biomarkers as useful tools for assessing environmental quality in the Oued Souss estuary (Bay of Agadir Morocco). Comp Biochem Physiol C 143:23-29

Albentosa M, Moyano F (2008) Influence of nutritional stress on digestive enzyme activities in juveniles of two marine clam species, Ruditapes decussates and Venerupis pullastra. J Sea Res 59:249-258

Amiard JC, Bacheley H, Barillé AL, Geffard A, Himery N (2004) Temporal changes in nickel and vanadium concentrations and in condition index and metallothionein levels in three species of molluscs following the 'Erika' oil spill. Aquat Living Resour 17:281-288

Amiard JC, Bodineau L, Bragigand V, Minier C, Budzinski H (2009) Quantification of contaminants. In: Amiard-Triquet C, Rainbow PS (eds) Environmental assessment of estuarine ecosystems: a case study. CRC Press, Boca Raton, p 31-57

Amiard-Triquet C (2009) Behavioral disturbances: the missing link between sub-organismal and supra-organismal responses to stress? Prospects based on aquatic research. Hum Ecol Risk Assess 15:87-110

Amiard-Triquet C, Rainbow PS (eds) (2009) Environmental assessment of estuarine ecosystems: a case study. CRC Press, Boca Raton
Banta GT, Holmer M, Jensen MH, Kristensen E (1999) Effects of two polychaete worms, Nereis divesicolor and Arenicola marina, on aerobic and anaerobic decomposition in a sandy marine sediment. Aquat Microb Ecol 19:189-204

Bernfeld P (1955) Amylases, $\alpha$ and $\beta$. In: Colowick SP, Kaplan NO (eds) Methods enzymol. Academic Press, New York, p 149-158

Blockwell SJ, Taylor EJ, Jones I, Pascoe D (1998) The influence of fresh water pollutants and interaction with Asellus aquaticus (L.) on the feeding activity of Gammarus pulex (L.). Arch Environ Contam Toxicol 34:41-47

Bocquené G, Galgani F, Truquet P (1990) Characterization and assay conditions for the use of AChE activity from several marine species in pollution monitoring. Mar Environ Res 30:75-89

Bonnard M, Roméo M, Amiard-Triquet C (2009) Effects of copper on the burrowing behavior of estuarine and coastal invertebrates, the polychaete Nereis diversicolor and the bivalve Scrobicularia plana. Hum Ecol Risk Assess 15: $11-26$

Bradford MM (1976) A rapid and sensitive method for the quantitation of microgram quantities of protein utilizing the principle of protein-dye binding. Anal Biochem 72: 248-254

Bragigand V, Amiard-Triquet C, Parlier E, Boury P, Marchand P, El Hourch M (2006) Influence of biological and ecological factors on the bioaccumulation of polybrominated diphenyl ethers in aquatic food webs from French estuaries. Sci Total Environ 368:615-626

> Burlinson FC, Lawrence AJ (2007) Development and validation of a behavioural assay to measure the tolerance of Hediste diversicolor to copper. Environ Pollut 145:274-278

Byrne PA, O'Halloran J (2001) The role of bivalve molluscs as tools in estuarine sediment toxicity testing: a review. Hydrobiologia 465:209-217

Calow P (1991) Physiological costs of combating chemical toxicants: ecological implications. Comp Biochem Physiol C 100:3-6

> Chapman PM, Wang F (2001) Assessing sediment contamination in estuaries. Environ Toxicol Chem 20:3-22

> Chapman PM, Ho KT, Munns WR Jr, Solomon K, Weinstein MP (2002) Issues in sediment toxicity and ecological risk assessment. Mar Pollut Bull 44:271-278

Chiffoleau JF, Chauvaud L, Amouroux D, Barats A, Duffour A, Pécheyran C, Roux N (2004) Nickel and vanadium contamination of benthic invertebrates following the 'Erika' wreck. Aquat Living Resour 17:273-280

> Comoglio L, Amin O, Roque A, Betancourt-Lozano M, Anguas D, Haro BM (2005) Evaluation of sublethal biomarkers in Litopenaeus vannamei on foodborne exposure to methyl parathion. Ecotoxicol Environ Saf 62:66-74

> Cooper NL, Bidwell JR (2006) Cholinesterase inhibition and impacts on behavior of the Asian clam, Corbicula fluminea, after exposure to an organophosphate insecticide. Aquat Toxicol 76:258-267

> Davey JT, Watson PG (1994) The architecture of the burrow of Nereis diversicolor and its quantification in relation to sediment-water exchange. J Exp Mar Biol Ecol 179:115-129

$>$ De Coen WM, Janssen CR (1997) The use of biomarkers in Daphnia magna toxicity testing II. Digestive enzyme activity in Daphnia magna exposed to sublethal concentrations of cadmium, chromium and mercury. Chemosphere 35: 1053-1067

> De Coen WM, Janssen CR (2003) The missing biomarker link: relationship between effects on the cellular energy allocation biomarker of toxicant-stressed Daphnia magna and corresponding population characteristics. Environ Toxicol 
Chem 22:1632-1641

De Gregori I, Pinochet H, Arancibia M, Vidal A (1996) Grain size effects on trace metals distribution in sediments from two coastal areas of Chile. Bull Environ Contam Toxicol 57:163-170

Dell'Omo G (2002) Behavioural ecotoxicology. John Wiley \& Sons, Chichester

DelValls TA, Conradi M (2000) Advances in marine ecotoxicology: laboratory tests versus field assessment data on sediment quality studies. Cienc Mar 26:39-64

$>$ Depledge MH, Rainbow PS (1990) Models of regulation and accumulation of trace metals in marine invertebrates: a mini-review. Comp Biochem Physiol C 97:1-7

Díez G, Soto M, Cantón L, Vaquero MC, Marigómez I (2000) Hediste (Nereis) diversicolor as bioindicator of metal and organic chemical bioavailability: a field study. Ecotoxicol Environ Restor 3:7-15

Durou C, Mouneyrac C, Amiard-Triquet C (2005) Tolerance to metals and assessment of energy reserves in the polychaete Nereis diversicolor in clean and contaminated estuaries. Environ Toxicol 20:23-31

Durou C, Poirier L, Amiard JC, Budzinski H and others (2007a) Biomonitoring in a clean and a multi-polluted estuary based on biomarkers and chemical analyses in the endobenthic worm Nereis diversicolor. Environ Pollut 148: $445-458$

Durou C, Smith BD, Roméo M, Rainbow PS and others (2007b) From biomarkers to population responses in Nereis diversicolor: assessment of stress in estuarine ecosystems. Ecotoxicol Environ Saf 66:402-411

Durou C, Mouneyrac C, Amiard-Triquet C (2008) Environmental quality assessment in estuarine ecosystems: use of biometric measurements and fecundity of the ragworm Nereis diversicolor (Polychaeta, Nereididae). Water Res 42:2157-2165

Eggleton J, Thomas KV (2004) A review of factors affecting the release and bioavailability of contaminants during sediment disturbance events. Environ Int 30:973-980

Ellman GL, Courtney KD, Andres V Jr, Featherstone RM (1961) A new rapid colorimetric determination of acetylcholinesterase activity. Biochem Pharmacol 7:88-95

Esselink P, Zwarts L (1989) Seasonal trend in burrow depth and tidal variation in feeding activity of Nereis diversicolor. Mar Ecol Prog Ser 56:243-254

Forbes VE, Palmqvist A, Bach L (2006) The use and misuse of biomarkers in ecotoxicology. Environ Toxicol Chem 25: $272-280$

> Galgani F, Bocquené G (1991) Semi-automated colorimetric and enzymatic assays for aquatic organisms using microplate readers. Water Res 25:147-150

Galloway TS, Brown RJ, Browne MA, Dissanayake A, Lowe D, Depledge MH, Jones MB (2006) The ECOMAN project: a novel approach to defining sustainable ecosystem function. Mar Pollut Bull 53:186-194

Gillet P, Torresani S (2003) Structure of the population and secondary production of Hediste diversicolor (O.F. Müller, 1776), (Polychaeta, Nereidae) in the Loire estuary, Atlantic coast, France. Estuar Coast Shelf Sci 56:621-628

Golovanova IL, Kuz'mina VV, Gobzhelian TE, Pavlov DF, Chuiko GM (1999) In vitro effects of cadmium and DDVP (dichlorvos) on intestinal carbohydrase and protease activities in freshwater teleosts. Comp Biochem Physiol C 122: 21-25

> Guilhermino L, Barros P, Silva MC, Soares AMVM (1998) Should the use of inhibitor of cholinesterases as a specific biomarker for organophosphate and carbamate pesticides be questioned? Biomarkers 3:157-163
Hamza-Chaffai A, Romèo M, Gnassia-Barelli M, El Abed A (1998) Effect of copper and lindane on some biomarkers measured in the clam Ruditapes decussates. Bull Environ Contam Toxicol 61:397-404

> Heugens EHW, Jan Hendricks A, Dekker T, Van Straalen NM, Admiraal W (2002) A review of the effects of multiple stressors on aquatic organisms and analysis of uncertainly factors for use in risk assessment. Crit Rev Toxicol 31: $247-284$

Holloway GJ, Sibly RM, Povey SR (1990) Evolution in toxinstressed environments. Funct Ecol 4:289-294

Lagauzère S, Terrail R, Bonzom JM (2009) Ecotoxicity of uranium to Tubifex tubifex worms (Annelida, Clitellata, Tubificidae) exposed to contaminated sediment. Ecotoxicol Environ Saf 72:527-537

Lam PKS, Gray JS (2003) The use of biomarkers in environmental monitoring programmes. Mar Pollut Bull 46: $182-186$

Lehtonen KK, Kankaanpa H, Leiniö S, Sipiä VO, Pflugmacher S, Sandberg-Kilpi E (2003) Accumulation of nodularin-like compounds from the cyanobacterium Nodularia spumigena and changes in acetylcholinesterase activity in the clam Macoma balthica during short-term laboratory exposure. Aquat Toxicol 64:461-476

> Loureiro S, Sampaio A, Brandão A, Nogueira AJA, Soares AMVM (2006) Feeding behaviour of the terrestrial isopod Porcellionides pruinosus Brandt, 1833 (Crustacea, Isopoda) in response to changes in food quality and contamination. Sci Total Environ 369:119-128

- Maltby L (1999) Studying stress: the importance of organismlevel responses. Ecol Appl 9:431-440

Maltby L, Kedwards TJ, Forbes VE, Grasman K and others (2001) Linking individual-level responses and populationlevel consequences. In: Baird DJ, Burton Jr GA (eds) Ecological variability: separating natural from anthropogenic causes of ecosystem impairment. SETAC, Pensacola, p 27-82

> McLoughlin N, Yin D, Maltby L, Wood RM, Yu H (2000) Evaluation of sensitivity and specificity of two crustacean biochemical biomarkers. Environ Toxicol Chem 19: 2085-2092

Méndez N (2006) Effects of teflubenzuron on sediment processing by members of the Capitella species-complex. Environ Pollut 139:118-124

> Meziane T, Retière C (2002) Croissance de juvéniles de Nereis diversicolor nourris avec des détritus d'halophytes. Oceanol Acta 25:119-124

> Møhlenberg F, Kiørboe T (1983) Burrowing and avoidance behaviour in marine organisms exposed to pesticide-contaminated sediment. Mar Pollut Bull 14:57-60

Moreira SM, Lima I, Ribeiro R, Guilhermino L (2006) Effects of estuarine sediment contamination on feeding and on key physiological functions of the polychaete Hediste diversicolor: laboratory and in situ assays. Aquat Toxicol 78:186-201

Mouneyrac C, Perrein-Ettajani H, Amiard-Triquet C (2009) Influence of anthropogenic stress on fitness and behaviour of a key-species of estuarine ecosystems, the ragworm Nereis diversicolor. Environ Pollut, doi:10.1016/j.envpol. 2009.07.028

> Najimi S, Bouhaimi S, Daubeze M, Zekhnini A, Pellerin J, Narbonne JF, Moukrin A (1997) Use of acetylcholinesterase in Perna perna and Mytilus galloprovincialis as a biomarker of pollution of Agadir marine bay (south Morocco). Bull Environ Contam Toxicol 58:901-912

> Neuhoff HG (1979) Influence of temperature and salinity on food conversion and growth of different Nereis species 
(Polychaeta, Annelida). Mar Ecol Prog Ser 1:255-262

Olla BL, Bejda AJ, Studholme AL, Pearson WH (1984) Sublethal effects of oiled sediment on the sand worm, Nereis (Neanthes) virens: Induced changes in burrowing and emergence. Mar Environ Res 13:121-139

Payne JF, Mathieu A, Melvin W, Fancey LL (1996) Acetylcholinesterase, an old biomarker with a new future? Field trials in association with two urban rivers and paper mill in Newfoundland. Mar Pollut Bull 32:225-231

Pérez E, Blasco J, Montserrat S (2004) Biomarker responses to pollution in two invertebrate species: Scrobicularia plana and Nereis diversicolor from the Cádiz bay (SW Spain). Mar Environ Res 58:275-279

Poirier L, Berthet B, Amiard JC, Jeanet AY, Amiard-Triquet C (2006) A suitable model for the biomonitoring of trace metal bioavailabilities in estuarine sediments: the annelid polychaete Nereis diversicolor. J Mar Biol Assoc UK 86: 71-82

Riisgård HU, Poulsen L, Larsen PS (1996) Phytoplankton reduction in near-bottom water caused by filter-feeding Nereis diversicolor-implications for worm growth and population grazing impact. Mar Ecol Prog Ser 141:47-54

RNO (Réseau National d'Observation) (2006) Surveillance de la qualité du milieu marin. Ministère de l'Environnement

Editorial responsibility: Inna Sokolova,

Charlotte, North Carolina, USA and Institut français de recherche pour l'exploitation de la mer (Ifremer), Paris \& Nantes

Ruus A, Ugland KI, Skaare JU (2002) Influence of trophic position on organochlorine concentrations and compositional patterns in a marine food web. Environ Toxicol Chem 21:2356-2364

Scaps P, Borot O (2000) Acetylcholinesterase activity of the polychaete Nereis diversicolor: effects of temperature and salinity. Comp Biochem Physiol C 125:377-383

Shipp E, Grant A (2006) Hydrobia ulvae feeding rates: a novel way to assess sediment toxicity. Environ Toxicol Chem 25: 3246-3252

> Solé M, Kopecka-Pilarczyk J, Blasco J (2009) Pollution biomarkers in two estuarine invertebrates, Nereis diversicolor and Scrobicularia plana, from a marsh ecosystem in SW Spain. Environ Int 35:523-531

Spies RB, Hardin DD, Toal JP (1988) Organic enrichment or toxicity? A comparison of the effects of kelp and crude oil in sediments on the colonization and growth of benthic infauna. J Exp Mar Biol Ecol 124:261-282

Wilding J, Maltby L (2006) Relative toxicological importance of aqueous and dietary metal exposure to a freshwater crustacean: implications for risk assessment. Environ Toxicol Chem 25:1795-1801

Submitted: February 26, 2009; Accepted: July 21, 2009

Proofs received from author(s): October 26, 2009 